NEG JINOTEP Vol 7 (2) (2020): 157-164

DOI: $10.17977 /$ um031v7i22020p157

JINOTEP (Jurnal Inovasi Teknologi Pembelajaran)

Kajian dan Riset Dalam Teknologi Pembelajaran

http://journal2.um.ac.id/index.php/jinotep/index

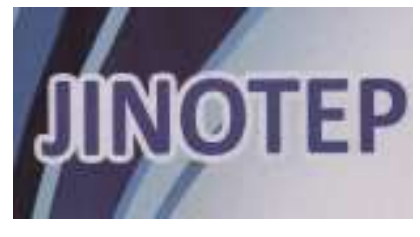

\title{
MENINGKATKAN KEMAMPUAN KOGNITIF KIMIA SISWA SMA MELALUI PENGEMBANGAN MEDIA PEMBELAJARAN BERBASIS ANDROID
}

\author{
Isna Rezkia Lukman', Andi Maria Ulfa ${ }^{2}$ \\ ${ }^{1}$ Universitas Malikussaleh-Aceh Utara, Indonesia \\ ${ }^{2}$ Universitas Cordova - Nusa Tenggara Barat, Indonesia
}

\section{Article History}

Received: 21-09-2020

Accepted: 30-09-2020

Published: 01-10-2020

\section{Keywords}

Kemampuan kognitif, Media Pembelajaran Berbasis Android, Tata Nama Senyawa Kimia

\begin{abstract}
Abstrak
Tujuan penelitian ini adalah untuk mengetahui kualitas media pembelajaran berbasis Android materi tata nama senyawa Kimia mengetahui perbedaan peningkatan kemampuan kognitif siswa SMA yang menggunakan mediapembelajaran pembelajaran berbasis Android materi tata nama senyawa Kimia dengan pembelajaran menggunakan LKS. Metode yang diguankan dalam penelitian ini adalah R\&D yang didaptasi model pengembangan Borg \& Gall dan 4D. Hasil dari pengembangan media pembelajaran berbasis android pada materi tata nama senyawa menunjukkan bahwa media yang dikembangkan layak untuk diaplikasikan dan memiliki kualitas sangat baik, baik dari aspek materi ataupun media. Kemudian, media pembelajaran yang dikembangkan juga mampu meningkatkan Kemampuan Kognitif Siswa setelah diaplikasikan ke dalam pembelajaran. Hal ini terbukti dari hasil uji hipotesis yang menunjukkan adanya perbedaan peningkatan Kemampuan Kognitif Siswa yang menggunakan media yang dikembangkan dengan yang menggunakan LKS.
\end{abstract}

\begin{abstract}
The purpose of this study was to determine the quality of Android-based learning media for chemical compound nomenclature material to know the differences in the cognitive ability enhancement of high school students who use Android-based learning media for chemical compound nomenclature materials by learning using $L K S$. The method used in this research is $R \& D$ adapted to the Borg \& Gall and $4 D$ development models. The results of the development of Android-based learning media on compound nomenclature material show that the media developed is feasible to be applied and has very good quality, both in terms of material and media aspects. Then, the learning media developed can also improve students' cognitive abilities after they are applied to learning. This is evident from the results of hypothesis testing which shows that there is a difference in the increase in students' cognitive abilities using developed media and those using LKS.
\end{abstract}

Corresponding author :

Adress: Dusun Labuhan RT 09 RW 04 Desa Labuhan Kertasari Kecamatan Taliwang, Kabupaten Sumbawa Barat-NTB 84455, Instansi: Universitas Cordova,

E-mail: yayaqe06011991@gmail.com,
2020 Universitas Negeri Malang p-ISSN 2406-8780 e-ISSN 2654-7953 
158 JINOTEP (Jurnal Inovasi dan Teknologi Pembelajaran) Kajian dan Riset dalam Teknologi Pembelajaran Vol. 7, No. 2, Oktober 2020, Hal. 157-164

\section{PENDAHULUAN}

Kemampuan kognitif merupakan salah satu kriteria penilaian dalam sistem pendidikan di Indonesia. Namun, salah satu masalah dalam pendidikan di Indonesia adalah masih rendahnya kemampuan kognitif siswa, terutama di bidang matematika dan ilmu pengetahuan alam (MIPA). Hal ini tampak pada hasil UN siswa SMA yang rata-rata nilai pada bidang MIPA lebih rendah dari bidang lainnya. Terutama pada mata pelajaran Kimia, hasil UN tahun 2019 mengalami penurunan dari tahun sebelumnya, yakni dari 51,13 menjadi 50,91. Padahal, rata-rata nilai UN pada mata pelajaran lainnya cenderung mengalami peningkatan. Hal ini kemungkinan besar disebabkan karena sebagian besar konsep pada ilmu Kimia bersifat abstrak, mikroskopik, berjenjang, dan terstruktur. Hal ini menyebabkan siswa dituntut untuk memahami keseluruhan konsep secara utuh, karena setiap konsep pada jenjang tertentu akan mempengaruhi konsep pada jenjang lainnya (Mentari, L., 2018; Prabowowati, K., 2014). Hal inilah yang cenderung membuat siswa merasa pelajaran Kimia adalah pelajaran yang sulit untuk dipahami.

Selain itu, penelitian menunjukkan kesulitan dalam membantu siswa mencapai motivasi belajar jika hanya menggunakan metode hafalan dan latihan, yang justru dapat menyebabkan siswa kehilangan kemampuan dan minat belajar (Mariscal, 2012; 2014). Salah satu cara menyiasati hal tersebut adalah dengan menggunakan permainan dalam pembelajaran. Namun, jika permainan tersebut terlalu menekankan pada pengetahuan ilmiah saja, aka nada kesenjangan antara unsur Kimia dengan kehidupan sehari-hari. Untuk itu, penggunaan media pembelajaran atau permainan juga sangat perlu diperhatikan (Li, M. C., 2013; Tsai, J. C., 2019; Hassinger-Das, B., 2018)

Salah satu materi yang dianggap sulit dalam Kimia adalah tata nama senyawa Kimia. Tata nama senyawa Kimia merupakan metode sistematis yang ditetapkan oleh International Union of Pure and Applied Chemistry (IUPAC) untuk memberi nama senyawa sesuai dengan strukturnya secara jelas dan tidak ambigu (Junior, et. al., 2018). Kesulitan yang dialami siswa dalam proses pembelajaran materi tata nama senyawa ini dikarenakan siswa kesulitan menghafal dan memahami konsep dalam penyusunan tata nama senyawa. Ditambah lagi selain harus paham, siswa juga harus teliti dalam menyusun tata nama senyawa karena penamaan yang sangat beragam dan bergantung pada kondisi tertentu. Hasil penelitian sebelumnya menunjukkan bahwa siswa mengalami kesulitan dalam materi tata nama senyawa Kimia dikarenakan masih banyak siswa yang belum hafal nama dan lambang unsur (Faizah, L.S., 2013).

Untuk mengatasi kesulitas siswa dalam pembelajaran materi tata nama senyawa, perlu adanya media pembelajaran yang mendukung proses belajar tersebut. Salah satunya dengan media pembelajaran berbasis Android. Android adalah salah satu sistem operasi untuk perangkat seluler (Musahrain, 2016). Seperti yang kita ketahui, perkembangan teknologi informasi dan komunikasi sangatlah pesat, termasuk dalam perangkat telepon seluler. Telepon seluler kini tak hanya menjadi sarana komunikasi, namun sudah menjadi gaya hidup bahkan kebutuhan. Masyarakat yang menggunakannya pun tidak hanya kalangan tertentu, tetapi seluruh kalangan, baik orang tua, remaja, bahkan anak-anak. Hasil survey penggunaan TIK tahun 2017 yang dilakukan kominfo menunjukkan bahwa $66,3 \%$ masyarakat memiliki smartphone dengan pengguna merupakan anak pra sekolah hingga orang tua. Namun, penggunaan smartphone untuk membaca saat offline hanya sekitar $7,42 \%$ jauh lebih rendah dengan penggunaan game offline yang hasil surveinya sebesar 26,58\%. Bahkan ketika online, penggunaan smartphone untuk belajar hanya $27,51 \%$ jauh lebih rendah dengan penggunaan untuk bermain game yang besarnya 47,05\% (Kominfo, 2017). Anak-anak menggunakan media dan teknologi sejak sebelum sarapan hingga saatnya tidur. Berbagai aktifitas dilakukan dengan telepon seluler hingga mampu menghabiskan 200 jam dalam sebulan untuk penggunaan telepon seluler tersebut (Hobbs, R., 2011).

Hasil survey tersebut menunjukkan bahwa penggunaan smartphone dalam pembelajaran 
masih sangat minim. Hal ini mungkin disebabkan masyarakat, terutama siswa SMA lebih tertarik untuk bermain game daripada belajar. Untuk itu, pemanfaatan smartphone dalam proses pembelajaran sangatlah tepat. Hasil penelitian menunjukkan, teknologi smartphone berbasis Android dalam pembelajaran mampu meningkatkan ketertarikan siswa sehingga pembelajaran menjadi lebih efektif yang berdampak pada peningkatan kemampuan kognitif siswa (Sakat., A.A., 2012; Ghavifekr, S., 2015; Ulfa, A. M., 2017). Ditambah dengan penggunaan teknologi smartphone berbasis Android dalam pembelajaran, siswa dapat belajar dimana saja dan kapan saja. Apalagi melihat kondisi saat ini dimana dunia sedang dilanda wabah covid-19 yang menyebabkan pembelajaran dilakukan secara daring. Dengan penggunaan smartphone, pembelajaran dapat dilakukan dengan lebih baik. Untuk itu, penggunaan media pembelajaran berbasis android dalam bentuk permainan tata nama senyawa dirasa sangat tepat, karena media yang dirancang dalam bentuk permainan diyakini mampu membuat siswa merasa tertarik (Woo, J. C., 2014). Selain itu, penelitian yang dilakukan oleh Lima, M. A. S., et. al (2019) menunjukkan bahwa permainan yang dikembangkan dalam bentuk aplikasi pembelajaran tata nama senyawa mampu menguji dan meningkatkan kemampuan siswa dengan cara yang menarik dan menyenangkan. Untuk itu dalam penelitiannya, mereka merekomendasikan pengembangan aplikasi pembelajaran Kimia dengan konsep-konsep yang baru.

Hal inilah yang membuat peneliti merasa perlu untuk mengambangkan media pembelajaran berbasis android ini. Media pembelajaran ini dirasa tepat dilakukan untuk meningkatkan kemampuan kognitif siswa pada materi tata nama senyawa Kimia dikarenakan konsep baru yang ditawarkan, yakni adanya materi yang bisa dipelajari siswa, kemudian adanya beberapa variasi dan level-level soal yang dikemas menarik sehingga ada tantangan tersendiri di setiap level yang harus diselesaikan oleh siswa. Siswa juga bisa menginput nama untuk menjadi karakter utama di media pembelajaran berbasis android ini.
Selain itu, media pembelajaran berbasis android ini dikembangkan sesuai dengan kurikulum yang sedang berlaku, yakni Kurikulum 2013 sehingga penerapannya dilakukan pada siswa yang sekolahnya menggunakan K13. Dengan demikian, diharapkan media pembelajaran Android dapat membantu siswa untuk memahami materi tatanama senyawa dengan cara yang menyenangkan. Hasil pengembangan media pembelajaran Android ini diharapkan dapat membantu peserta didik dalam memahami materi dan diharapkan juga dapat meningkatkan kreativitas dan hasil belajar peserta didik SMA secara signifikan.

Tujuan yang ingin dicapai pada penelitian ini diantaranya untuk mengetahui kualitas media pembelajaran berbasis Android materi tata nama senyawa Kimia. Di samping itu untuk mengetahui perbedaan peningkatan kemampuan kognitif siswa SMA yang menggunakan mediapembelajaran pembelajaran berbasis Android materi tata nama senyawa Kimia dengan pembelajaran menggunakan LKS.

Adapun pertanyaan penelitian yang hendak dijawab antara lain. Bagaimanakah kualitas media pembelajaran berbasis Android materi tata nama senyawa Kimia yang dikembangkan?. Kemudian adakah perbedaan peningkatan kemampuan kognitif siswa SMA yang menggunakan mediapembelajaran pembelajaran berbasis Android materi tata nama senyawa Kimia dengan pembelajaran menggunakan LKS?.

\section{METODE}

Pengembangan media pembelajaran berbasis Android dilakukan dengan mengadaptasi model pengembangan Borg \& Gall dan 4D. Pengembangan produk meliputi 7 tahapan, yakni

1. Analisis Pendahuluan, terdiri dari analisis kurikulum, analisis tujuan, analisis peserta didik, analisis kebutuhan dan studi literatur.

2. Tahap kedua yakni perencanaan yang meliputi proses menyusun tes kriteria, menetapkan model penyajian media dan simulasi penyajian model pembelajaran

3. Tahap ketiga pengembangan produk awal, dimulai dengan kegiatan mengumpulkan 
160 JINOTEP (Jurnal Inovasi dan Teknologi Pembelajaran) Kajian dan Riset dalam Teknologi Pembelajaran Vol. 7, No. 2, Oktober 2020, Hal. 157-164

bahan dan referensi, membuat story board dan flowchart dan membuat produk wal

4. Validasi dan Penilaian kualitas, dimulai dengan validasi produk awal oleh ahli materi dan media kemudian melakukan revisi hasil validasi, selanjutnya produk yang sudah direvisi (Produk I) dinilai oleh peer reviewer dan pendidik Kimia. Hasil penilaian dijadikan acuan untuk melakukan revisi produk. Hasil revisi berupa produk II

5. Evaluasi

a. Dilakukan uji pengembangan awal terhadap produk II kemudian dilakukan revisi berdasarkan hasil penilaian. Hasil revisi berupa Produk III

b. Dilakukan uji pengembangan lanjutan dari III. Hasil pengujian dijadikan acuan untuk merevisi produk. Hasil revisi berupa produk IV

c. Dilakukan uji lapangan terhadap produk IV. Hasil pengujian dijadikan acuan untuk merevisi produk. Hasilnya berupa produk akhir.

6. Dilakukan penyempurnaan media pembelajaran

7. Diseminasi media ke masyarakat

Untuk mengetahui pengaruh media terhadap peningkatan kemampuan kognitif siswa, penelitian dilakukan di SMA Negeri di Yogyakarta dengan sampel sebanyak 64 siswa yang dibagi menjadi dua kelompok, yakni kelompok eksperimen 32 siswa dan kelompok kontrol 32 siswa. Penelitian dilakukan dengan metode quasi eksperimen (eksperimen semu) dengan desain penelitian non-equivalent comparison-group design. Untuk lebih jelasnya, bisa dilihat pada tabel 1 .

Tabel 1. Rancangan Nonequivalent ControlGroup Design

\begin{tabular}{llllll}
\hline No & Variabel & $\begin{array}{c}\text { Kelom- } \\
\text { pok }\end{array}$ & $\begin{array}{c}\text { Pre- } \\
\text { test }\end{array}$ & $\begin{array}{c}\text { Per- } \\
\text { lakuan }\end{array}$ & $\begin{array}{c}\text { Post- } \\
\text { test }\end{array}$ \\
\hline \multirow{2}{*}{1} & $\begin{array}{c}\text { Kemampuan } \\
\text { Kognitif }\end{array}$ & $\begin{array}{l}\text { Eksperi- } \\
\text { men }\end{array}$ & $\mathrm{O}_{1}$ & $\mathrm{X}_{1}$ & $\mathrm{O}_{3}$ \\
\cline { 3 - 6 } & & Kontrol & $\mathrm{O}_{2}$ & - & $\mathrm{O}_{4}$ \\
\hline
\end{tabular}

Keterangan:

$\mathrm{X}_{1}$ : peserta didik menggunakan media pembelajaran Kimia berbasis Android
$\mathrm{O}_{1}$ : soal pretest sebelum materi tata nama senyawa menggunakan media pembelajaran Kimia berbasis Android

$\mathrm{O}_{2}$ : soal pretest sebelum materi tata nama senyawa

$\mathrm{O}_{3}$ : soal posttest setelah materi tata nama senyawa menggunakan media pembelajaran Kimia berbasis Android

$\mathrm{O}_{4}$ : soal posttest setelah materi tata nama senyawa

Untuk mendukung pelaksanaan penelitian, digunakan instrumen penelitian berupa kueisioner yang dijelaskan pada Tabel 2.

Tabel 2. Instrumen Penelitian

\begin{tabular}{|c|c|c|}
\hline No & Instrumen & Data yang diperoleh \\
\hline \multirow[t]{2}{*}{1} & \multicolumn{2}{|c|}{ Tahap Analisis Pendahuluan (1) } \\
\hline & $\begin{array}{l}\text { Angket analisis } \\
\text { kebutuhan awal }\end{array}$ & $\begin{array}{l}\text { Data kebutuhan awal peserta } \\
\text { didik }\end{array}$ \\
\hline \multirow[t]{5}{*}{2} & \multicolumn{2}{|c|}{ Tahap Validasi dan Penilaian Kualitas Produk (4) } \\
\hline & $\begin{array}{l}\text { a. Lembar validasi } \\
\text { dan penilaian } \\
\text { materi }\end{array}$ & $\begin{array}{l}\text { Validitas pakar Kimia dan nilai } \\
\text { kualitas produk terkait } \\
\text { kebenaran materi dan } \\
\text { kesesuaian pembelajaran } \\
\text { dengan kurikulum } 2013\end{array}$ \\
\hline & $\begin{array}{l}\text { b. Lembar validasi } \\
\text { dan penilaian } \\
\text { media }\end{array}$ & $\begin{array}{l}\text { Validitas pakar media dan nilai } \\
\text { kualitas produk terkait } \\
\text { kesesuaian audio visual dan } \\
\text { rekayasa perangkat lunak } \\
\text { dengan tujuan pembuatan } \\
\text { produk }\end{array}$ \\
\hline & $\begin{array}{l}\text { c. } \\
\text { Lembar } \\
\text { penilaian peer } \\
\text { reviewer, dan } \\
\text { pendidik Kimia }\end{array}$ & $\begin{array}{lr}\text { Nilai kualitas } & \text { produk } \\
\text { berdasarkan } & \text { aspek } \\
\text { pembelajaran, } & \text { aspek } \\
\text { materi, aspek audio visual } \\
\text { dan rekayasa perangkat } \\
\text { lunak }\end{array}$ \\
\hline & & 2) $\begin{array}{lr}\text { Masukan/saran perbaikan } \\
\text { produk awal untuk } \\
\text { menghasilkan produk } \\
\text { revisi }\end{array}$ \\
\hline \multirow[t]{7}{*}{3} & Evaluasi (5) & \\
\hline & \multicolumn{2}{|c|}{ Tahap Uji Pengembangan Awal } \\
\hline & $\begin{array}{l}\text { a. Lembar } \\
\text { penilaian } \\
\text { peserta didik }\end{array}$ & $\begin{array}{l}\text { a. Nilai kualitas produk } \\
\text { berdasarkan pembelajaran } \\
\text { \& materi dan tampilan \& } \\
\text { oprasional media } \\
\text { b. Masukan/saran perbaikan } \\
\text { produk awal untuk } \\
\text { menghasilkan produk } \\
\text { revisi }\end{array}$ \\
\hline & \multicolumn{2}{|c|}{ Tahap Uji Pengembangan } \\
\hline & $\begin{array}{l}\text { b. Lembar } \\
\text { penilaian } \\
\text { peserta didik }\end{array}$ & $\begin{array}{llr}\text { a. Nilai kualitas produk } \\
\text { berdasarkan pembelajaran } \\
\text { \& materi dan tampilan \& } \\
\text { oprasional media } \\
\text { b. Masukan/saran perbaikan } \\
\text { produk awal untuk } \\
\text { menghasilkan produk } \\
\text { revisi }\end{array}$ \\
\hline & \multicolumn{2}{|c|}{ Tahap Uji Lapangan (Eksperimen) } \\
\hline & $\begin{array}{l}\text { c. Tes hasil } \\
\text { belajar Kimia }\end{array}$ & $\begin{array}{l}\text { Data kemampuan kognitif } \\
\text { siswa }\end{array}$ \\
\hline
\end{tabular}




\section{HASIL}

Hasil pengembangan media pembelajaran berupa game tata nama senyawa Kimia yang diaplikasikan pada perangkat berbasis Android. Adapun tampilan dari game tersebut dapat dilihat pada Gambar 1, 2, dan 3.

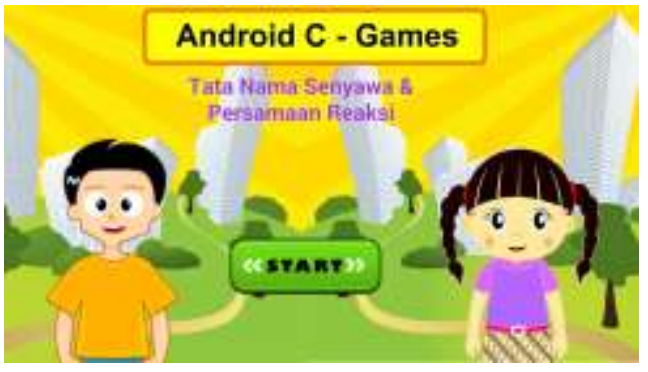

Gambar 1. Tampilan halaman depan aplikasi

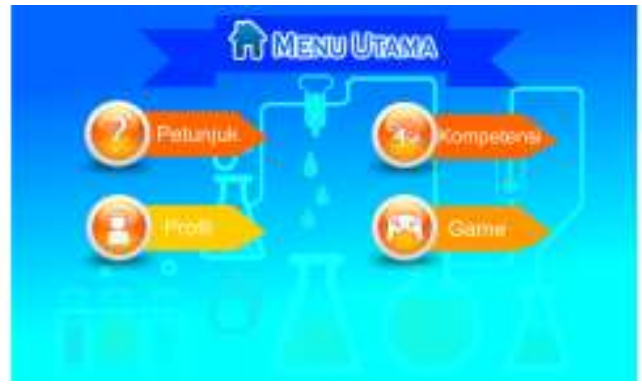

Gambar 2. Tampilan menu utama aplikasi

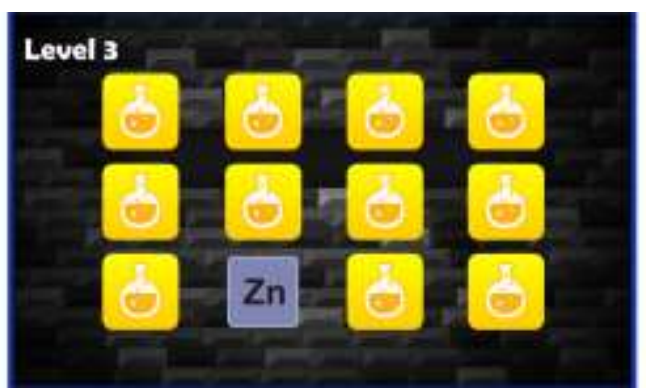

Gambar 3. Tampilan salah satu jenis game pada aplikasi

Selanjutnya, hasil penilaian terhadap aspek media dan materi dapat dilihat pada gambar 4 dan 5 .

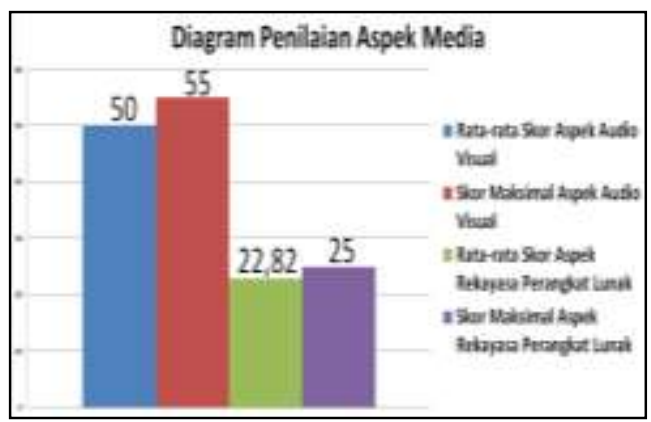

Gambar 4. Penilaian Aspek Media
Gambar 4 menunjukkan skor rata-rata hasil penilaian yang dilakukan oleh ahli media, peer reviewer, dan pendidik Kimia. Untuk aspek audio visual diperoleh skor rata-rata sebesar 50 yang termasuk dalam kategori sangat baik. Untuk aspek rekayasa perangkat lunak diperoleh skor rata-rata sebesar 22,82 yang termasuk dalam kategori sangat baik. Hal ini menunjukkan perangkat mediapembelajaran berbasis android yang dikembangkan, layak untuk diujicobakan ke tahap selanjutnya. Untuk hasil penilaian terhadap materi pembelajaran bias dilihat pada gambar 5 .

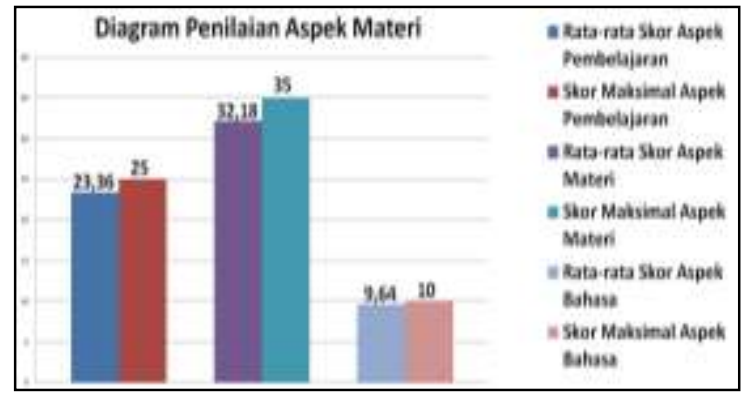

Gambar 5. Penilaian Aspek Materi

Gambar 5 menunjukkan hasil penilaian yang dilakukan oleh ahli materi, peer reviewer, dan pendidik Kimia. Untuk pembelajaran diperoleh skor rata-rata sebesar 23,36 yang termasuk dalam kategori sangat baik. Untuk aspek materi diperoleh skor rata-rata sebesar 32,18 yang termasuk dalam kategori sangat baik. Begitupun dengan aspek bahasa yang memperoleh skor rata-rata sebesar 9,64 yang termasuk dalam kategori sangat baik. Dengan demikian, perangkat media pembelajaran berbasis android yang dikembangkan, layak untuk diujicobakan ke tahap selanjutnya yakni uji coba, yakni ujicoba pengembangan awal, ujicoba pengembangan, dan uji lapangan. Untuk ujicoba pengembangan awal dan pengembangan media pembelajaran yang dikembangkan dinilai oleh siswa SMA yang sudah mendapatkan materi tata nama senyawa. Hasilnya ditunjukkan oleh Tabel 3.

Berdasarkan Tabel 3, hasil ujicoba terhadap siswa menunjukkan hasil yang sangat baik dari aspek pembelajaran dan materi juga aspek tampilan dan operasional media. Berdasarkan hasil penilaian dari tahap validasi hingga ujicoba pengembangan, seluruh responden member skor yang rata-ratanya 
162 JINOTEP (Jurnal Inovasi dan Teknologi Pembelajaran) Kajian dan Riset dalam Teknologi Pembelajaran Vol. 7, No. 2, Oktober 2020, Hal. 157-164

termasuk dalam kategori sangat baik. Dengan demikian, media pembelajaran yang dikembangkan akan dilanjutkan pada tahap uji lapangan guna melihat pengaruh dari penerapan media terhadap kemampuan kognitif siswa. Data hasil penerapan media pembelajaran dapat dilihat pada Tabel 4 .

Tabel 3. Hasil Pengujian produk

\begin{tabular}{|c|c|c|c|c|c|c|}
\hline \multirow{2}{*}{$\begin{array}{l}\mathbf{N} \\
\mathbf{o}\end{array}$} & \multirow{2}{*}{ Aspek } & \multicolumn{2}{|c|}{$\begin{array}{c}\text { Skor rata- } \\
\text { rata }\end{array}$} & \multirow{2}{*}{$\begin{array}{l}\text { Rata } \\
\text {-rata }\end{array}$} & \multirow{2}{*}{$\begin{array}{c}\text { Skor } \\
\text { Mak } \\
\text { s }\end{array}$} & \multirow{2}{*}{$\begin{array}{c}\text { Kate- } \\
\text { gori }\end{array}$} \\
\hline & & $\begin{array}{c}\text { Awa } \\
\text { l }\end{array}$ & $\begin{array}{c}\text { Akhi } \\
\mathbf{r}\end{array}$ & & & \\
\hline 1 & $\begin{array}{l}\text { Pembelajara } \\
\mathrm{n} \text { dan Materi }\end{array}$ & 21,8 & 23 & 22,4 & 25 & $\begin{array}{l}\text { Sanga } \\
\text { t Baik }\end{array}$ \\
\hline 2 & $\begin{array}{l}\text { Tampilan } \\
\text { dan } \\
\text { Operasional } \\
\text { Media }\end{array}$ & 43,6 & 44,07 & 43,83 & 50 & $\begin{array}{l}\text { Sanga } \\
\text { t Baik }\end{array}$ \\
\hline
\end{tabular}

Tabel 4. Rata-rata Nilai Pretest dan Posttest

\begin{tabular}{cccc}
\hline \multicolumn{2}{c}{ Kelas } & $\begin{array}{c}\text { Eks- } \\
\text { perimen }\end{array}$ & Kontrol \\
\hline Jumlah Peserta Didik & 32 & 32 \\
\hline Pretest & Rata-rata & 6,125 & 5,156 \\
\hline & $\begin{array}{c}\text { Ketuntasan } \\
(\%)\end{array}$ & 0 & 0 \\
\hline Posttest & Rata-rata & 87,06 & 83,25 \\
\hline \multicolumn{2}{c}{ ketuntasan } & 100 & 96,8 \\
\hline \multicolumn{2}{c}{$>$} & 0,862 & 0,82 \\
\hline \multicolumn{2}{c}{ Kategori } & Tinggi & Tinggi \\
\hline
\end{tabular}

Hasil pre-test dan post-test menunjukkan rata-rata peningkatan dari kemampuan kognitif siswa antara kelompok control dengan kelompok eksperimen sama-sama ada pada kategori tinggi. Selanjutnya, untuk mengetahui pengaruh dari media pembelajaran dilakukan uji mann whitney $U$ test dengan bantuan aplikasi SPSS 26 untuk menentukan kesimpulan penelitian. Uji mann whitney U test merupakan prosedur pengujian non parametric yang digunakan untuk menguji hipotesis mengenai median dari 2 sampel yang saling bebas. Dengan kata lain, Pengujian MannWhitney digunakan dalam pengujian hipotesis nol yang menyatakan bahwa tidak ada perbedaan yang sesungguhnya antara kedua kelompok data dan dimana data tersebut diambil dari sampel yang tidak saling terkait (Sriwidadi, T., 2011). Dalam penelitian ini, digunakan uji ini karena hasil uji prasyarat menunjukkan bahwa data kelas control tidak terdistribusi normal sehingga pengujian menggunakan statistik non parametrik. Hasil pengujian ditampilkan pada Tabel 5 .

Berdasarkan hasil uji statistik mann whitney $U$ test diperoleh nilai signifikansi sebesar 0,009 yang berarti lebih kecil dari taraf signifikansi yang ditetapkan sebesar 0,05. Hal ini menunjukkan bahwa kesimpulan yang dapat ditarik adalah Ho ditolak dan Ha diterima atau terdapat perbedaan peningkatan kemampuan kognitif siswa SMA yang menggunakan media pembelajaran pembelajaran berbasis Android materi tata nama senyawa Kimia dengan pembelajaran menggunakan LKS.

Tabel 5. Hasil Uji Mann Whitney U Test

\begin{tabular}{cc}
\hline Signifikansi & Keterangan \\
\hline \hline 0,009 & Ho ditolak dan Ha diterima \\
\hline PEMBAHASAN &
\end{tabular}

Salah satu upaya untuk mengembangkan keterampilan berfikir kreatif siswa adalah dengan menciptakan lingkungan pembelajaran yang mampu melibatkan siswa serta memberi pengalaman nyata dalam pembelajaran (Corebima, 2017). Topik tata nama senyawa Kimia dianggap sebagai salah satu materi Kimia yang tidak sistematis, tidak penting, dan berbasis hafalan oleh siswa (Turaçoğlu, 2013). Sehingga untuk memberi pengalaman nyata pada topik tata nama senyawa Kimia dibutuhkan media pembelajaran yang sesuai.

Dalam dunia pendidikan maupun penelitian, permainan menjadi salah satu hal yang sering dibahas. Karena siswa yang mengalami kesulitan dalam pembelajaran, justru akan merasa tertantang dengan adanya permainan ini, sehingga pembelajaran menggunakan permainan mampu menjadikan pembelajaran yang lebih efektif karena berpusat pada siswa (Gupta, T., 2019). Permainan digital juga menjadi bentuk baru dari konten interaktif dan kolaboratif di dalam pembelajaran (Pivec, P., 2013). Namun, perlu diperhatikan bahwa permainan edukatif harus hemat biaya, sederhana, tidak memakan waktu, dan mudah diadaptasi (Cha, J., 2018). Untuk itu, media pembelajaran yang dikembangkan pada penelitian ini merupakan media pembelajaran berbasis android dengan format Android package (.apk) menggunakan software Adobe Flash Professional CS 6 dengan action script 3 
dengan karakteristik sebagai berikut.. (1) Dapat dioperasikan dengan menggunakan OS Android. (2) Mendukung pembelajaran Kimia materi tata nama senyawa. (3) Dapat digunakan dimana saja dan kapan saja serta menyajikan media pembelajaran yang relevan dengan visualisasi media pembelajaran yang menarik

Hasil penilaian media pembelajaran yang dikembangkan menunjukkan bahwa dari aspek materi maupun media, media pembelajaran yang dikembangkan layak untuk digunakan bahkan termasuk dalam kategori sangat baik. Hal ini membuktikan bahwa media yang dikembangkan mudah dimengerti baik secara bahasa, maupun materi tata nama senyawa yang disuguhkan. Selain itu, penilian aspek media juga termasuk dalam kategori yang sangat baik sehingga media yang dikembangkan mudah dioperasikan oleh pengguna. Visualisasi yang menarik, soal yang variatif dan penggunaan yang praktis tentu menjadi kelebihan dari media yang dikembangkan. Hal ini sesuai dengan hasil penelitian sebelumnya yang mengembangakan media pembelajaran berbasis android dengan karakteristik visualisasi yang menarik, praktis dan fleksibel, serta memiliki evaluasi soal yang variatif. Yang pada akhirnya mampu meningkatkan motivasi kemampuan kognitif siswa (Lubis, I.R., 2015). Penelitian ini juga sejalan dengan penelitian hang dilakukan Jabbour (2014) yang mengungkapkan bahwa penggunaan mobile learning dapat berdampak pada peningkatan outcomes peserta didik. Bayir (2014) menunjukkan bahwa permainan yang dikembangkan untuk memfasilitasi pembelajaran unsur, senyawa, dan tabel periodik mampu memperkuat konsep Kimia siswa serta memicu minat siswa dalam pembelajaran Kimia.

Kemudian media pembelajaran yang dikembangkan diaplikasikan dalam proses pembelajaran di kelas guna melihat pengaruhnya terhadap peningkatan kemampuan kognitif siswa. Hasilnya menunjukkan adanya perbedaan peningkatan kemampuan kognitif antara kelas ekperimen dan kelas control. Hasil ini dibuktikan dengan uji mann whitney $U$ test dengan taraf signifikansi 0,009 yang berarti Ho ditolak dan Ha diterima. Hal ini sesuai dengan penelitian yang menunjukkan bahwa penggunaan teknologi, terutama teknologi smartphone berbasis Android dalam pembelajaran mampu meningkatkan ketertarikan peserta didik sehingga pembelajaran di kelas menjadi lebih efektif yang berdampak pada peningkatan kemampuan akademik (Ghavifek, S., 2015; Ulfa, A. M., 2017). Peningkatan kemampuan kognitif siswa salah satunya dikarenakan peningkatan motivasi belajar melalui media pembelajaran yang mampu mengembangkan kompetensi ilmiah siswa, seperti pemecahan masalah dalam menyelesaikan suatu permainan (Tsai, J. C., 2020)

\section{SIMPULAN}

Berdasarkan tujuan dan hasil penelitian, maka dapat disimpulkan bahwa kualitas media pembelajaran berbasis Android materi tata nama senyawa Kimia yang dikembangkan adalah sangat baik dan layak untuk digunakan sesuai dengan hasil penilaian yang diberikan oleh ahli materi, ahli media, peer reviewer, pendidik Kimia, dan siswa. Nilai rata-rata hasil penilaian menunjukkan media yang dikembangkan memiliki kategori sangat baik.

Kemudian, terdapat perbedaan peningkatan kemampuan kognitif siswa SMA yang menggunakan media pembelajaran pembelajaran berbasis Android materi Tata Nama Senyawa Kimia dengan pembelajaran menggunakan LKS dilihat dari hasil analisis data menggunakan uji mann whitney $U$ test dengan taraf signifikansi 0,009 yang berarti Ho ditolak dan Ha diterima.

\section{DAFTAR RUJUKAN}

Bayir, E. (2014). Developing and playing chemistry games to learn about elements, compounds, and the periodic table: Elemental Periodica, Compoundica, and Groupica. Journal of Chemical Education, 91(4), 531-535.

Cha, J., Kan, S. Y., \& Chia, P. W. (2018). "Spot the differences" Game: An Interactive Method That Engage Students in Organic Chemistry Learning. Journal of the Korean Chemical Society, 62(2).

Corebima, A. D., Susilo, H., \& Zubaidah, S. (2017). Creative Thinking of Low Academic Student Undergoing Search Solve Create and Share Learning Integrated with Metacognitive Strategy. International Journal of Instruction, $10(2)$.

Faizah, L. S. I., Afandy, D., \& Su'aidy, M. (2013). Studi Pemahaman Konsep Tata Nama IUPAC Senyawa Anorganik Siswa Kelas X SMA 
Negeri 9 Malang Semester 2 Tahun Ajaran 2012/2013. Universitas Negeri Malang, Malang.

Ghavifekr, S., \& Rosdy, W. A. W. (2015). Teaching and learning with technology: Effectiveness of ICT integration in schools. International Journal of Research in Education and Science, 1(2), 175-191.

Gupta, T., \& Belford, R. E. (2019). Conclusion: Technology Integration in Chemistry Education and Research: What Did We Learn and What Can We Expect Going Forward?. In Technology Integration in Chemistry Education and Research (TICER) (pp. 281-301). American Chemical Society.

Hassinger-Das, B., Bustamante, A. S., Hirsh-Pasek, K., \& Golinkoff, R. M. (2018). Learning landscapes: Playing the way to learning and engagement in public spaces. Education Sciences, 8(2), 74.

Hobbs, R. (2011). Digital and media literacy: Connecting culture and classroom. Corwin Press.

Jabbour, K. K. (2014). An analysis of the effect of mobile learning on Lebanese higher education. Informatics in Education-An International Journal, 13(1), 1-16.

Júnior, J. N., Nobre, D. J., do Nascimento, R. S., Torres Jr, G. S., Leite Jr, A. J. M., Monteiro, A. J., ... \& Rojo, M. J. (2018). Interactive computer game that engages students in reviewing organic compound nomenclature. Journal of Chemical Education, 95(5), 899-902.

Kominfo. 2017. Survey Penggunaan TIK 2017. Jakarta: Pusat Penelitian dan Pengembangan Aplikasi Informatika dan Informasi dan Komunikasi Publik Badan Penelitian dan Pengembangan Sumber Daya Manusia Kementerian Komunikasi dan Informatika Republik Indonesia

Li, M. C., \& Tsai, C. C. (2013). Game-based learning in science education: A review of relevant research. Journal of Science Education and Technology, 22(6), 877-898.

Lima, M. A., Monteiro, Á. C., Melo Leite Junior, A. J., de Andrade Matos, I. S., Alexandre, F. S. O., Nobre, D. J., ... \& da Silva Júnior, J. N. (2019). Game-based application for helping students review chemical nomenclature in a fun way.

Lubis, I. R., \& Ikhsan, J. (2015). Pengembangan media pembelajaran kimia berbasis android untuk meningkatkan motivasi belajar dan prestasi kognitif peserta didik SMA. Jurnal Inovasi Pendidikan IPA, 1(2), 191-201.

Mariscal, A. J., Oliva-Martínez, J. M., \& Almoraima Gil, M. L. (2015). Students' perceptions about the use of educational games as a tool for teaching the periodic table of elements at the high school level. Journal of Chemical Education, 92(2), 278-285.
Mariscal, A. J., Oliva Martínez, J. M., \& Bernal Márquez, S. (2012). An educational card game for learning families of chemical elements. Journal of Chemical Education, 89(8), 10441046.

Mentari, L., Suardana, I. N., \& Subagia, I. W. (2017). Analisis Miskonsepsi Siswa SMA pada pembelajaran Kimia untuk materi larutan penyangga. Jurnal Pendidikan Kimia Undiksha, 1(1).

Musahrain, M. Developing Android-Based Mobile Learning as a Media in Teaching English. In Proceeding of the International Conference on Teacher Training and Education (Vol. 2, No. 1, pp. 307-313).

Prabowowati, K., \& Hadisaputro, S. (2014). Penerapan media chemscool dengan metode guided note taking pada pemahaman konsep siswa. Jurnal inovasi pendidikan kimia, 8(2).

Pivec, P., \& Pivec, M. (2013). Digital Games: Changing Education, One Raid at a Time. In Developments in Current Game-Based Learning Design and Deployment (pp. 253272). IGI Global.

Sakat, A. A., Zin, M. Z. M., Muhamad, R., Anzaruddin, A., Ahmad, N. A., \& Kasmo, M. A. (2012). Educational Technology Media Method In Teaching And Learning Progress. Advances in Natural and Applied Sciences, 6(3), 484-490.

Sriwidadi, T. (2011). Penggunaan uji mann-whitney pada analisis pengaruh pelatihan wiraniaga dalam penjualan produk baru. Binus Business Review, 2(2), 751-762.

Tsai, J. C., Cheng, P. H., Liu, S. Y., \& Chang, C. Y. (2019). Using board games to teach socioscientific issues on biological conservation and economic development in Taiwan. Journal of Baltic Science Education, 18(4), 634.

Tsai, J. C., Chen, S. Y., Chang, C. Y., \& Liu, S. Y. (2020). Element enterprise tycoon: Playing board games to learn chemistry in daily life. Education Sciences, 10(3), 48.

TURAÇOĞLU, İ., ALPAT, Ş., \& Ellez, A. M. (2013). Effects of Jigsaw on Teaching Chemical Nomenclature. Education \& Science/Egitim ve Bilim, 38(167).

Ulfa, A. M., Sugiyarto, K. H., \& Ikhsan, J. (2017, May). The effect of the use of android-based application in learning together to improve students' academic performance. In AIP Conference Proceedings (Vol. 1847, No. 1, p. 050008). AIP Publishing LLC.

Woo, J. C. (2014). Digital game-based learning supports student motivation, cognitive success, and performance outcomes. Journal of Educational Technology \& Society, 17(3), 291307. 